\title{
Parenting styles and alcohol use among adolescents: A longitudinal study
}

\author{
Víctor Martínez-Loredo, Sergio Fernández-Artamendi, Sara Weidberg, Irene \\ Pericot, Carla López-Núñez, José R. Fernández-Hermida \& \\ Roberto Secades \\ University of Oviedo (Spain)
}

\begin{abstract}
Parenting style has been identified as one of the most important risk and protective factors for substance use in adolescents. Evidence suggests that the influence of each parenting style on adolescent's substance use varies across countries. Research studies with Spanish population have been mostly restricted to cross-sectional designs, limiting the interpretation of directionality in the relationship between parenting styles and adolescent substance use. This longitudinal study explores the predictive validity of perceived parenting style on prospective drug use and alcohol related problems in a sample of adolescents. Participants were 346 adolescents (53.64\% males) who were assessed twice in a period of two years. In the first wave participants were 12.89 years old $(S D=0.54)$. Logistic regression analyses were performed to estimate the prospective relationship between perceived parenting style at first wave and substance involvement outcomes at the second. Adolescents that perceived their parents as neglectful had higher risk of developing an alcohol use disorder two years later [odds ratio $(\mathrm{OR}): 2.14 ; 95 \%$ confidence interval $(\mathrm{CI}): 1.18-3.86(p=.012)$ ]. The findings of this study indicate that special attention should be given to those adolescents who perceived their parenting style as neglectful.
\end{abstract}

Keywords: Parenting styles, adolescents, alcohol use disorder, risk factor.

Estilos educativos y uso de alcohol en adolescentes: un estudio longitudinal: Los estilos educativos han sido identificados como uno de los factores de riesgo y protección más importantes para el uso de sustancias en adolescentes. La evidencia sugiere que la influencia de cada estilo en el uso de sustancias varía entre países. Los estudios con población española se han basado en diseños transversales, limitando la interpretación de la direccionalidad en la relación entre los estilos educativos y el uso de sustancias en adolescentes. Este estudio longitudinal explora la validez predictiva de los estilos educativos percibidos en el uso posterior de sustancias y problemas relacionados con el alcohol. Los participantes fueron 346 adolescentes (53.64\% varones) que fueron evaluados dos veces en un período de dos años. En la primera ola, los participantes tenían 12.89 años $(D T=0.54)$. Se realizaron análisis de regresión logística para estimar la relación entre los estilos educativos percibidos en la ola uno y las variables relacionadas con sustancias en la ola dos. Los adolescentes que percibían a sus padres como negligentes tenían un mayor riesgo de desarrollar trastorno por uso de sustancias dos años después: odds ratio $(\mathrm{OR})=2.14 ; 95 \%$ intervalo de confianza (IC): 1.18-3.86] $(p=.012)$. Este estudio indica que se debería dar especial atención a aquellos adolescentes que perciben el estilo educativo de sus padres como negligente.

Palabras clave: Estilos educativos, adolescentes, trastorno por uso de sustancias, factor de riesgo.

Correspondence: Víctor Martínez-Loredo. Department of Psychology. University of Oviedo. Plaza Feijoo, s/n. C.P.: 33003 Oviedo (Spain). E-mail: martinezlvictor@uniovi.es 
Recent data shows that alcohol, tobacco and cannabis are the most used drugs among US (National Institute on Drug Abuse, 2015) and European adolescents (European Commission, 2012; European Monitoring Centre for Drugs and Drug Addiction, 2012; Pérez-Fuentes et al., 2015; Steketee, Jonkman, Berten, \& Vettenburg, 2013). Among secondary students in Spain, a national survey indicates that rates of frequent alcohol, tobacco and cannabis use are 74\%, 29.7\% and 16.1\%, respectively (Plan Nacional sobre Drogas, 2014). Moreover, mean age at onset of these drugs is quite low, ranging between 13.6 and 14.9 years.

Drinking at an early age is associated with poor academic performance (Hemphill et al., 2014), unsafe driving and violent behavior (Estévez \& Emler, 2011; Miller et al., 2015), as well as blackouts (Zeigler et al., 2005) and subsequent alcohol abuse or dependence (Beil-Gawelczyk, Bratek, Banach, \& Beil, 2014)

Among the risk factors for alcohol use in adolescents, parental behaviors have been reported as a major source of influence (Calafat, García, Juan, Becoña, \& FernándezHermida, 2014). More specifically, factors such as parental substance use (Macleod et al., 2008) and abuse (Biederman, Faraone, Monuteaux, \& Feighner, 2000) and perceived parental approval toward drugs (Brooks-Russell et al., 2015) have been associated with alcohol and drug use. Nevertheless, one of the most important risk factors for adolescent substance use is inadequate parenting style (Calafat et al., 2014).

Previous research defines parenting styles based on the combination of two dimensions, namely warmth and strictness (Rohner, 1990). As a result, four possible parenting styles emerge: authoritative (high warmth, high strictness), authoritarian (low warmth, high strictness), indulgent (high warmth, low strictness) and neglectful (low warmth, low strictness). Previous work indicate that authoritative parenting style is the most protective against alcohol and drug use (Darling \& Cumsille, 2003; Hartman et al., 2015; Hoffmann \& Bahr, 2014; Lamborn, Mounts, Steinberg, \& Dornbusch, 1991; Montgomery, Fisk, \& Craig, 2008; Shakya, Christakis, \& Fowler, 2012). Nonetheless, most studies have been conducted in Anglo-Saxon contexts, so there is scarce evidence on which parenting style functions as a protective factor within the European countries (Calafat et al., 2014), and it may depends on the cultural background that surrounds parent-child relationships (Becoña et al., 2012).

The results of four studies conducted in Spain are mixed. In contrast with Anglo-Saxon studies, two studies showed that besides authoritative parenting, the indulgent style also functions as a protective factor for adolescent substance use (García \& Gracia, 2010; Gracia, Fuentes, García, \& Lila, 2012). Moreover, two studies found better outcomes for adolescents under the indulgent style than the authoritative one (García \& Gracia, 2009; Martínez, Fuentes, García, \& Madrid, 2013). However, these results must be interpreted with caution due to the cross-sectional nature which limits the interpretation of the possible causal relationship between parenting styles and adolescent 
drug use (Becoña et al., 2012). Additionally, alcohol and drug use and abuse were not assessed through standardized questionnaires, and in most cases they were just secondary analyses and not a primary goal of the study.

We sought to address these gaps in knowledge by drawing on data from a longitudinal design to assess the predictive validity of perceived parenting style on prospective drug use and alcohol related problems in a wide sample of early adolescents from the general population in Spain.

\section{METHOD}

\section{Participants}

The initial sample was made up of 645 adolescents attending the second course of 16 Spanish secondary schools. The schools were selected following a random stratified and incidental procedure. All adolescents were assessed twice in a period of two years. In order to control for the relationship between parental style and substance use, only those adolescents who were abstinent from alcohol, tobacco and cannabis in the first wave were considered for the analyses. Of the initial 645 adolescents, 399 (61.9\%) met the inclusion criteria, and an additional 53 were excluded to the erratic answers according to the Infrequency Scale. As a result, 346 (53.64\% male) participants were included in the study.

In the first wave, the mean age of adolescents was 12.89 years old $(S D=.54)$. In the second wave, two years later, adolescents were 14.92 years old $(S D=.50)$.

\section{Procedure}

Participation in the study was voluntary and was approved by the centers and the education authorities. None of the participants refused to be assessed and participants were given guarantees of total confidentiality and anonymity. This study was approved by the Ethics Committee of the Spanish Education Ministry.

After the acceptance of participation from schools, students were surveyed in their own classroom with computerized versions of paper-pencil self-reports (using Samsung Galaxy Tab2 10.1 tablets). Participants were sitting at individual desks and two trained experimenters provided the instructions on how to complete the battery, which required approximately one hour. Participants were retested after two years under the same conditions.

\section{Measures}

Sociodemographic characteristics. Data regarding participants' age, school year, sex and country of birth was collected.

Infrequency scale. In order to detect random answers, an infrequency scale was used (Oviedo Infrequency Scale, INF-OV) (Fonseca-Pedrero, Paino-Piñeiro, 
Lemos-Giráldez, Villazón-García, \& Muñiz, 2009). This instrument comprises 12 items that are introduced throughout the assessment. Participants were required to respond to these Likert-type items (from totally disagree to totally agree) about obvious facts such as 'I know people who wear glasses' or 'I have sometimes watched films on TV'. Following the guidelines established by the authors, participants with more than three wrong answers are excluded from the analyses.

Parenting styles. The Spanish adaptation (García \& Gracia, 2010) of the Rohner's PARQ/C Scale (Rohner, 1990) was used. This self-report evaluates two dimensions of parenting styles independently for both parents, as perceived by adolescents: warmth and strictness. The warmth dimension comprises 8 items which refer to warmth, affection, care, comfort, concern, or support that adolescents can experience from their parents. The internal consistency of the warmth scale in the Spanish adaptation was $\alpha=.81$. With regard to strictness, this dimension includes 13 items referring to the degree in which adolescents perceive control from their parents. The internal consistency of the Spanish adaptation was also good $(\alpha=.79)$. A global score for warmth and strictness for both parents was created. After that, scores were dichotomized by the median, taking into account the gender of the adolescents. Finally, scores were assigned a parenting style based on the author's classification with the author (Rohner, 1990): neglectful (low warmth, low strictness), indulgent (high warmth, low strictness), authoritarian (low warmth, high strictness), and authoritative (high warmth, high strictness).

Substance use. Prevalence of alcohol, tobacco and cannabis use in the last month was evaluated using the items from the ESPAD (European School Survey Project on Alcohol and Other Drugs, 2007).

Problem drinking. Participants were also asked about intoxication episodes and/or binge drinking (BD) in the previous 30 days. Regarding BD it was defined as the consumption of 5 or more standard drink units (SDUs) -4 or more for girls - on a single period of 2 hours (Parada et al., 2011). The presence of alcohol-related problems was evaluated using the Spanish version (López-Núñez, Fernández-Artamendi, Fernández-Hermida, Campillo-Álvarez, \& Secades-Villa, 2012) of the Rutgers Alcohol Problem Index (RAPI) (White \& Labouvie, 1989). This self-report has shown excellent reliability (Cronbach $\alpha=.91$ ) with Spanish adolescents. The instrument consists of 23 Likert-type items with responses ranging from 0 to 3 on the frequency of alcohol-related events in the past year. A cut-off score equal or higher than 7 points is suggested in the Spanish adaptation as an indicator of problem drinking.

Alcohol use disorder. DSM-5 criteria were used to detect the presence of an Alcohol use disorder (AUD) (American Psychiatric Association, 2013). 


\section{Data analyses}

Descriptive analyses of participant's characteristics were carried out. Due to the Kolmogorov-Smirnov and Shapiro-Wilk's sensitivity to larger sample sizes, kurtosis lower than 7 and skewness lower than 2 were considered as normal (Kim, 2013). Also, values greater than $3.29 \mathrm{SD}$ from the mean scores and disconnected from the distribution in each measure were recoded to a unit greater than the next most extreme value (Tabachnick, 2007). With the aim of testing the prospective relationship between parenting styles and substance involvement outcomes, a set of logistic regressions were performed. Following a backward stepwise method, parenting styles were introduced in the models as dummy codes, using the most prevalent category as reference. Percentage of explained variance of models was assessed by both Cox and Snell R square, and Nagelkerke R squared indices. Data was analyzed using the statistical package SPSS for Windows (version 19, SPSS Inc., Chicago IL, USA).

\section{RESULTS}

The sample was composed of nearly the same gender percentage $(50.3 \%$ females), with a mean age of 12.89 years $(S D=0.54)$. The average test-retest interval was 753.54 days $(S D=33.95)$. The majority of participants $(94.5 \%)$ were born in Spain and $79.26 \%$ lived with both parents. Regarding parenting styles, most participants perceived their parents as having an indulgent style (30.9\%), followed by authoritative (28.9\%), neglectful (25.7\%), and authoritarian (14.5\%) ones. Prevalence of substance involvement variables at second wave are described in table 1 .

Table 1. Prevalence of substance involvement by parenting styles at wave two $(N=346)$

\begin{tabular}{|c|c|c|c|c|c|c|c|}
\hline Variables & Total & Negligent & Indulgent & Authoritative & Authoritarian & $F / \chi^{2}$ & $p$ \\
\hline Alcohol use $^{\mathrm{a}}$ & 35.5 & 42.7 & 30.8 & 35 & 34 & $3.08^{1}$ & .379 \\
\hline Tobacco use ${ }^{\mathrm{a}}$ & 10.4 & 6.7 & 8.4 & 14 & 14 & $3.82^{1}$ & .282 \\
\hline Cannabis use $^{\mathrm{a}}$ & 4.9 & 4.5 & 3.7 & 7 & 4 & $1.37^{1}$ & .712 \\
\hline $\begin{array}{l}\text { Intoxication } \\
\text { episodes }^{\mathrm{a}}\end{array}$ & 8.1 & 9 & 6.5 & 8 & 10 & $0.69^{1}$ & .876 \\
\hline Binge drinking $^{\mathrm{a}}$ & 9 & 4.5 & 9.3 & 11 & 12 & $3.27^{1}$ & .352 \\
\hline RAPI score ${ }^{b}$ & $0.82(2.60)$ & $0.72(2.39)$ & $0.64(2.56)$ & $1(2.92)$ & $1(2.4)$ & $0.449^{2}$ & .718 \\
\hline $\begin{array}{l}\text { Alcohol-related } \\
\text { problem }^{\text {a }}\end{array}$ & 5.2 & 5.6 & 3.7 & 6 & 6 & $0.69^{1}$ & .876 \\
\hline DSM-5 criteria $^{a}$ & 17.1 & 25.8 & 14 & 17 & 8 & $8.45^{1^{*}}$ & .037 \\
\hline
\end{tabular}

RAPI mean scores did not differ significantly between parenting styles $\left(F_{(3,346)}=0.449, p=.718\right)$. Concerning chi-square analyses, those participants who met DSM-5 criteria for an AUD perceived their parents more as neglectful (39\% of 
participants) than having other parenting style $\left(\chi^{2}(3, N=346)=8.45, p=.037\right.$, Cramer's V = .156).

According to logistic regressions, the only significant variable predicted by parenting styles was the presence of DSM-5 criteria for an AUD, $\chi^{2}(1, N=346)=6.11$, $p<.05$. The model explained between $1.8 \%$ (Cox and Snell $\mathrm{R}$ square) and $2.9 \%$ (Nagelkerke R squared) of the variance. More specifically, adolescents who perceived their parents as neglectful were more likely to meet DSM-5 criteria for an AUD than those who perceived their parents as having one of the other parenting styles (OR : $2.14 ; 95 \%$ CI: $1.18-3.86 ; p=.012)$.

\section{DISCUSSION}

The present study aimed to assess the predictive value of the four perceived parental styles on the prospective use of alcohol, tobacco and cannabis, as well as on the presence of problem alcohol use according to several standardized measures. According to the results of this longitudinal study, a parental style perceived as neglectful by the adolescents resulted a significant predictor of the presence of an AUD according to the DSM-5 criteria.

Our results confirm previous data from similar studies, since the neglectful parental style has been traditionally considered a risk factor for different substance use (Adalbjarnardottir \& Hafsteinsson, 2001). However, according to our results, neglectful parenting style has not been associated with other drug use, contrary to previous studies where it has been associated with tobacco (Courtois et al., 2007; Radziszewska, Richardson, Dent, \& Flay, 1996), alcohol (Bahr \& Hoffmann, 2010; Shucksmith, Glendinning, \& Hendry, 1997) and cannabis (Courtois et al., 2007; Montgomery et al., 2008). These results could be due to the low prevalence of use of drugs other than alcohol in our study, which could be a consequence of the young age of participants. The low prevalence of drug use may have hindered the detection of additional significant relationships between parenting styles and substance use. On the other hand, and contrary to previous studies with Spanish adolescents, our study has a longitudinal design that controls for possible reciprocal influences between initial drug use and parenting styles (Mezzich et al., 2007).

Our results confirm that adolescents' perception of a parental style as neglectful is a significant risk factor for developing an AUD two years later. The reasons why neglectful parenting style is a risk factor have been largely discussed. It could be the combination of low warmth and low control that characterize this parenting style (Steinberg, Blatt-Eisengart, \& Cauffman, 2006) what makes it a risk factor for an alcohol use disorder in adolescents. Previous studies remark the benefits associated to the high warmth, including affect and empathetic communication with children (Jiménez, Murgui, Estévez, \& Musitu, 2007). In fact, the parenting styles identified as protector factors in 
Spanish and Latin contexts are the authoritative and indulgent, both characterized by high levels of warmth (Calafat et al., 2014). Therefore, it is not surprising that perception of low warmth results a significant predictor of an AUD in adolescents. On the other hand, high perceived control is a protective factor that may prevent from alcohol and substance use (Van der Vorst, Engels, Meeus, Dekovic, \& Vermulst, 2006; Velleman, Templeton, $\&$ Copello, 2005), putting adolescents under neglectful parenting styles at risk.

\section{CONCLUSIONS}

According to our results, among Spanish adolescents, a neglectful parenting style perceived at 12 years old significantly predicts the presence of an AUD two years later. Low warmth and low control associated to this parenting style could make it a significant risk factor. On the other hand, neither the authoritative, indulgent or authoritarian parenting styles resulted in significant risk or protective factors for an AUD among adolescents. Similarly, parenting style was not a significant predictor of other drug use, high risk patterns of alcohol use or problem drinking. The findings of this study indicate that special attention should be given to those adolescents who perceived their parenting style as neglectful in order to implement appropriate prevention strategies. Specific interventions could be aimed at this group of adolescents as soon as 12 years old in order to prevent further development of an AUD. Future longitudinal studies should start evaluating adolescents at an even earlier age in order to take into account the most precocious use of drugs, using additional measures of parenting styles as reported by parents.

\section{Funding}

The present research project (Ref: MSSSI-12-2012/131) has been funded by the National Plan on Drugs (Plan Nacional Sobre Drogas, PNSD) of the Ministry of Health, Social Services and Equality, and by the Council for Economy and Work (FC-15GRUPIN14-047). The authors declare no conflicts of interest.

\section{REFERENCES}

Adalbjarnardottir, S., \& Hafsteinsson, L.G. (2001). Adolescents' perceived parenting styles and their substance use: Concurrent and longitudinal analyses. Journal of Research on Adolescence, 11, 401-423. doi: 10.1111/1532-7795.00018

American Psychiatric Association. (2013). Diagnostic and Statistical manual of mental disorders (5th ed.). Arlington, VA: American Psychiatric Association.

Bahr, S.J., \& Hoffmann, J.P. (2010). Parenting Style, Religiosity, Peers, and Adolescent Heavy Drinking. Journal of Studies on Alcohol and Drugs, 71, 539-543. doi:10.15288/jsad.2010.71.539 
Becoña, E., Martínez, Ú., Calafat, A., Juan, M., Fernández-Hermida, J.R., \& Secades-Villa, R. (2012). Parental styles and drug use: A review. Drugs-Education Prevention and Policy, 19, 1-10. doi: 10.3109/09687637.2011.631060

Beil-Gawelczyk, J., Bratek, A., Banach, M., \& Beil, S. (2014). Association of early drinking onset with subsequent alcohol abuse. European Psychiatry, 29. doi: 10.1016/s09249338(14)78687-0

Biederman, J., Faraone, S.V., Monuteaux, M.C., \& Feighner, J.A. (2000). Patterns of alcohol and drug use in adolescents can be predicted by parental substance use disorders. Pediatrics, 106, 792-797. doi: 10.1542/peds.106.4.792

Brooks-Russell, A., Conway, K.P., Liu, D., Xie, Y., Vullo, G. C., Li, K., ... Simons-Morton, B. (2015). Dynamic patterns of àdolescent substance use: Results from a nationally representative sample of high school students. Journal of Studies on Alcohol and Drugs, 76, 962-970. doi: 10.15288/jsad.2015.76.962

Calafat, A., García, F., Juan, M., Becoña, E., \& Fernández-Hermida, J.R. (2014). Which parenting style is more protective against adolescent substance use? Evidence within the European context. Drug and Alcohol Dependence, 138, 185-192. doi: 10.1016/j.drugalcdep.2014.02.705

Courtois, R., Caudrelier, N., Legay, E., Lalande, G., Halimi, A., \& Jonas, C. (2007). Influence of parental tobacco dependence and parenting styles on adolescents' tobacco use. La Presse Médicale, 36, 1341-1349. doi: 10.1016/j.lpm.2007.02.017

Darling, N., \& Cumsille, P. (2003). Theory, measurement, and methods in the study of family influences on adolescent smoking. Addiction, 98, 21-36. doi: 10.1046/j.13600443.98.s1.3.x

Estévez, E., \& Emler, N.P. (2011). Assessing the links among adolescent and youth offending, antisocial behaviour, victimization, drug use, and gender. International Journal of Clinical and Health Psychology, 11(2), 269-289. Retrieved from http://www.aepc.es/ijchp/

European Commission. (2012). Special Eurobarometer 385. Attitudes of europeans towards tobacco. Retrieved from http://ec.europa.eu/health/tobacco/docs/eurobaro_attitudes_ towards_tobacco_2012_en.pdf

European Monitoring Centre for Drugs and Drug Addiction. (2012). 2012 Annual report on the state of the drugs problem in Europe. Retrieved from http://www.aaaprevent.eu/

European School Survey Project on Alcohol and Other Drugs. (2007). ESPAD Student Questionnaire. Retrieved from http://www.espad.org/Uploads/Documents /ESPAD_Questionnaire_2007.pdf

Fonseca-Pedrero, E., Paino-Piñeiro, M., Lemos-Giráldez, S., Villazón-García, U., \& Muñiz, J. (2009). Validation of the Schizotypal Personality Questionnaire-Brief Form in adolescents. Schizophrenia Research, 111, 53-60. doi: 10.1016/j.schres.2009.03.006.

García, F., \& Gracia, E. (2009). Is always authoritative the optimum parenting style? Evidence from Spanish families. Adolescence, 44(173), 101-131.

García, F., \& Gracia, E. (2010). ¿Qué estilo de socialización parental es el idóneo en España? Un estudio con niños y adolescentes de 10 a 14 años. [What style of parental socialization is ideal in Spain. A study of children and adolescents aged 10 to 14 years]. Infancia $y$ Aprendizaje, 33, 365-384. doi: 10.1174/021037010792215118

Gracia, E., Fuentes, M.C., García, F., \& Lila, M. (2012). Perceived neighborhood violence, parenting styles, and developmental outcomes among Spanish adolescents. Journal of Community Psychology, 40, 1004-1021. doi: 10.1002/jcop.21512

Hartman, J.D., Patock-Peckham, J.A., Corbin, W.R., Gates, J.R., Leeman, R.F., Luk, J.W., \& King, K.M. (2015). Direct and indirect links between parenting styles, self-concealment 
(secrets), impaired control over drinking and alcohol-related outcomes. Addictive Behaviors, 40, 102-108. doi: 10.1016/j.addbeh.2014.08.009

Hemphill, S.A., Heerde, J.A., Scholes-Balog, K.E., Herrenkohl, T.I., Toumbourou, J.W., \& Catalano, R.F. (2014). Effects of early adolescent alcohol use on mid-adolescent school performance and connection: A Longitudinal study of students in Victoria, Australia and Washington State, United States. Journal of School Health, 84, 706-715. doi: $10.1111 /$ josh. 12201

Hoffmann, J.P., \& Bahr, S.J. (2014). Parenting Style, Religiosity, Peer Alcohol Use, and Adolescent Heavy Drinking. Journal of Studies on Alcohol and Drugs, 75, 222-227. doi: 10.15288/jsad.2014.75.222

Jiménez, T.I., Murgui, S., Estévez, E., \& Musitu, G. (2007). Family communication and delinquent behavior among spanish adolescents: The mediating role of self-esteem. Revista Latinoamericana de Psicologia, 39, 473-485. Retrieved from http://www.journals.elsevier.com/revista-latinoamericana-de-psicologia/

Kim, H.Y. (2013). Statistical notes for clinical researchers: assessing normal distribution (2) using skewness and kurtosis. Restorative Dentistry \& Endodontics, 38, 52-54. doi: 10.5395/rde.2013.38.1.52

Lamborn, S.D., Mounts, N.S., Steinberg, L., \& Dornbusch, S.M. (1991). Patterns and adjustment among adolescents from authoritative, authoritarian, indulgent, and neglectful families. Child Development, 62, 1049-1065. doi: 10.1111/j.1467-8624.1991.tb01588.x

López-Núñez, C., Fernández-Artamendi, S., Fernández-Hermida, J.R., Campillo-Álvarez, A., \& Secades-Villa, R. (2012). Spanish Adaptation and Validation of the Rutgers Alcohol Problems Index (RAPI). International Journal of Clinical and Health Psychology, 12(2), 251-264. Retrieved from http://www.aepc.es/ijchp/

Macleod, J., Hickman, M., Bowen, E., Alati, R., Tilling, K., \& Smith, G.D. (2008). Parental drug use, early adversities, later childhood problems and children's use of tobacco and alcohol at age 10: birth cohort study. Addiction, 103, 1731-1743. doi: 10.1111/j.13600443.2008.02301.x

Martínez, I., Fuentes, M.C., García, F., \& Madrid, I. (2013). The parenting style as protective or risk factor for substance use and other behavior problems among Spanish adolescents. Adicciones, 25(3), 235-242. Retrieved from http://www.adicciones.es /index.php/adicciones/

Mezzich, A.C., Tarter, R.E., Kirisci, L., Feske, U., Day, B.S., \& Gao, Z. (2007). Reciprocal influence of parent discipline and child's behavior on risk for substance use disorder: A nine-year prospective study. American Journal of Drug and Alcohol Abuse, 33, 851-867. doi: 10.1080/00952990701653842

Miller, P.G., Butler, E., Richardson, B., Staiger, P.K., Youssef, G.J., Macdonald, J.A., ... Olsson, C.A. (2015). Relationships between problematic alcohol consumption and delinquent behaviour from adolescence to young adulthood. Drug and Alcohol Review. Advanced online publication. doi: 10.1111/dar.12345

Montgomery, C., Fisk, J.E., \& Craig, L. (2008). The effects of perceived parenting style on the propensity for illicit drug use: The importance of parental warmth and control. Drug and Alcohol Review, 27, 640-649. doi: 10.1080/09595230802392790

National Institute on Drug Abuse. (2015). Drug Facts. Nationwide Trends. Retrieved from http://www.drugabuse.gov/publications/drugfacts/nationwide-trends

Parada, M., Corral, M., Caamano-Isorna, F., Mota, N., Crego, A., Rodríguez, S., \& Cadaveira, F. (2011). Definición del concepto de consumo intensivo de alcohol adolescente (binge drinking) [Definition of adolescent binge drinking]. Adicciones, 23(1), 53-63. Retrieved from http://www.adicciones.es/index.php/adicciones 
Pérez-Fuentes, M.C., Gázquez J.J., Molero, M.M., Cardila, F., Martos, A., Barragán, A.B., ... \& Mercader, I. (2015). Impulsividad y consumo de alcohol y tabaco en adolescentes. European Journal of Investigation in Health, Psychology and Education, 5(3), 371-382. doi: 10.1989/ejihpe.v5i3.139

Plan Nacional sobre Drogas. (2014). Encuesta estatal sobre uso de drogas en estudiantes de enseñanzas secundarias (ESTUDES) 2012-2013, España. Madrid: Delegación del Gobierno para el Plan Nacional sobre Drogas: Retrieved from http://www.pnsd.msssi.gob.es/Categoria2/observa/estudios/home.htm.

Radziszewska, B., Richardson, J.L., Dent, C.W., \& Flay, B.R. (1996). Parenting style and adolescent depressive symptoms, smoking, and academic achievement: Ethnic, gender, and SES differences. Journal of Behavioral Medicine, 19, 289-305. doi: $10.1007 / \mathrm{BF} 01857770$

Rohner, R.P. (1990). Handbook for the study of parental acceptance and rejection (3rd ed.). Storrs, CT: Rohner Research Publications.

Shakya, H.B., Christakis, N.A., \& Fowler, J.H. (2012). Parental Influence on Substance Use in Adolescent Social Networks. Archives of Pediatrics \& Adolescent Medicine, 166, 11321139. doi: 10.1001/archpediatrics.2012.1372

Shucksmith, J., Glendinning, A., \& Hendry, L. (1997). Adolescent drinking behaviour and the role of family life: a Scottish perspective. Journal of Adolescence, 20, 85-101. doi: 10.1006/jado.1996.0066

Steinberg, L., Blatt-Eisengart, I., \& Cauffman, E. (2006). Patterns of competence and adjustment among adolescents from authoritative, authoritarian, indulgent, and neglectful homes: A replication in a sample of serious juvenile offenders. Journal of Research on Adolescence, 16, 47-58. doi: 10.1111/j.1532-7795.2006.00119.x

Steketee, M., Jonkman, H., Berten, H., \& Vettenburg, N. (2013). Alcohol use among adolescents in Europe. Environmental research and preventive actions. Retrieved from http://www.emcdda.europa.eu/publications/annual-report/2012

Tabachnick, B.G., \& Fidell, L.S. (2007). Using Multivariate Statistics. Boston, MA: Pearson Education.

Van der Vorst, H., Engels, R.C., Meeus, W., \& Dekovic, M. (2006). Parental attachment, parental control, and early development of alcohol use: a longitudinal study. Psychology of Addictive Behaviors, 20, 107-116. doi: 10.1037/0893-164x.20.2.107

Velleman, R.D., Templeton, L.J., \& Copello, A.G. (2005). The role of the family in preventing and intervening with substance use and misuse: a comprehensive review of family interventions, with a focus on young people. Drug and Alcohol Review, 24, 93-109. doi: $10.1080 / 09595230500167478$

White, H.R., \& Labouvie, E.W. (1989). Towards the assessment of adolescent problem drinking. Journal of Studies on Alcohol, 50, 30-37. doi: 10.15288/jsa.1989.50.30

Zeigler, D.W., Wang, C.C., Yoast, R.A., Dickinson, B.D., McCaffree, M.A., Robinowitz, C.B., \& Sterling, M.L. (2005). The neurocognitive effects of alcohol on adolescents and college students. Preventive Medicine, 40, 23-32. doi: 10.1016/j.ypmed.2004.04.044

Received: September 16th, 2015

Modifications received: November 12th, 2015

Accepted: November 15th, 2015 